\title{
Rubem Alves e o entretempo messiânico: variações sobre corpo, poder e esperança
}

\author{
Alexandre Marques Cabral* \\ Edson Fernando de Almeida**
}

\section{Resumo}

Este artigo tem como objetivo apresentar o conceito de temporalidade messiânica ou entretempo messiannico em Rubem Alves. Tal temporalidade está construída sobre três elementos fundamentais da sua antropologia teológica, a saber, o corpo, o poder e a esperança. Em um primeiro momento, sob a chave da esperança, mapeamos duas temporalidades do mundo que se entrechocam em seus escritos, quais sejam, o realismo e a utopia. Em seguida, sob a chave do corpo, apresentamos a noção de teogonia somatológica como imprescindível para a compreensão da temporalidade do entretempo nestes mesmos escritos. Finalmente, sob a chave do poder, desenvolvemos a noção entretempo que em Rubem Alves diz respeito às descontinuidades qualitativas que interrompem experiências históricas que amarram as possibilidades criativas da condição humana.

Palavras-chave: Rubem Alves, corpo, teogonia, temporalidade messiânica, entretempo

\section{Rubem Alves and the messianic between-time: variations on body, power and hope}

\section{Abstract}

This article aims to show the concept of messianic temporality or messianic betweentime [entretempo] in Rubem Alves. Such temporality is built on three fundamental elements of his theological anthropology, namely, the body, the power and the hope. At first, under the key of hope, we map two temporalities of the world that bump in his writings, namely, realism and utopia. Then, under the key to the body, we present the notion of somatological theogony as essential for the understanding of the temporality of between-time in these same writings. Finally, under the key of power, we develop the notion of between-time that in Rubem Alves concerns the qualitative

\footnotetext{
* Professor do Departamento de Filosofia da UERJ. alxcbl@yahoo.com.br .

** Universidade Federal de Juiz de Fora. Professor do departamento de Ciência da Religião da UFJF. edsonfernandodealmeida@gmail.com .
} 
discontinuities that interrupt historical experiences that tie up the creative possibilities of the human condition.

Keywords: Rubem Alves, body, theogony, messianic temporality, between-time

\section{Rubem Alves y el entretiempo mesiánico: variaciones sobre cuerpo, poder y esperanza}

\section{Resumen}

Este artículo tiene como objetivo presentar el concepto del temporalidad mesiánica o entretiempo mesiánico en Rubem Alves. Tal temporalidad se construye sobre tres elementos fundamentales de su antropología teológica, a saber, el cuerpo, el poder y la esperanza. En un primer momento, bajo la llave de la esperanza, mapeamos dos temporalidades del mundo que chocan en sus escritos, a saber, el realismo y la utopía. Luego, bajo la clave del cuerpo, presentamos la noción de teogonía somatológica como esencial para la comprensión de la temporalidad del entretiempo en estos mismos escritos. Finalmente, bajo la llave del poder, desarrollamos la noción del entretiempo que en Rubem Alves concierne a las discontinuidades cualitativas que interrumpen las experiencias históricas que atan las posibilidades creativas de la condición humana.

Palabras clave: Rubem Alves, cuerpo, teogonía, temporalidad mesiánica, entretiempo.

\section{Introdução}

Se levarmos em conta a noção de obra autoral e seus respectivos supostos metafísicos, a saber, os conceitos de causalidade (o/a autor/a é a fonte causal da obra) e de totalidade (toda obra é expressão de uma totalidade unificadora da pluralidade de elementos que a compõem), então, é preciso dizer: Rubem Alves não possui uma obra. Primeiramente, porque o percurso de seu pensamento suspendeu a normatividade da subjetividade nuclear, tal qual pensada pelo pensamento cartesiano e kantiano (respectivamente, subjetividade enquanto res extensa e subjetividade transcendental), o que inviabilizou por completo supor uma ação causal do sujeito epistemológico como sentido último de seus textos. Por outro lado, não é possível supor uma unidade global ou total unificadora de seus textos, ainda que seus temas por vezes se repitam e muitas de suas abordagens também reapareçam ao longo dos anos. Isso porque faz parte do pensamento alvesiano a suspensão da noção de sistema, tanto no sentido teológico de uma teologia sistemática, quanto filosoficamente, no sentido de um sistema metafísico de compressão de mundo. Não é à toa que Alves fala em variações de temas específicos (ALVES, 1982), forma de pensar que marca claramente o percurso de sua produção. É que as variações assinalam uma apropriação de símbolos, conceitos, modos de pensar de certa tradição histórico-cultural, 
com a finalidade de recriar sentidos pelos quais o viver e o morrer possam definitivamente valer a pena. Isso equivale a dizer que produzir variações exige relação com pensadores/as, temas, conceitos, símbolos diversos, com a finalidade de engendrar sentidos que articulem a existência no mundo qualificando afirmativamente suas experiências. Com o propósito políticoestético-existencial de legitimação da vida, por motivos que ficarão claros ao longo do presente trabalho, o pensamento alvesiano abre mão dos sistemas globais de explicação de mundo e trabalha na finitude das variações. Ora, dessa forma não falaremos em obra alvesiana, mas de caminhos de pensamento alvesianos. Por isso, é um claro sinal de fidelidade hermenêutica se relacionar com os textos de Rubem Alves, assumindo a tarefa de uma apropriação criadora, isto é, se colocando o desafio de produzir, neles, variações.

Este artigo, por conseguinte, possui como eixo hermenêutico o conceito alvesiano de variação, que, como visto sinteticamente acima, assinala a reapropriação criadora de temas, conceitos, autores/as, questões etc., com a finalidade de produzir sentido qualificador das experiências humanas de mundo. O próprio Rubem Alves diz que a tarefa de uma variação de um tema dado não é outra senão "construir uma arquitetura simbólica que evoque e represente a presença escondida do tema proposto, fazendo com que todos os cantos e recantos do nosso mundo entrem em reverberações harmônicas, cantando partes de uma polifonia, revelando assim um mágico encanto, onipresente..." (ALVES, 1982, p. 25) Já a noção de encantamento traz para a cena alvesiana o componente estético do seu método de pensamento. Contudo, ao pretender evocar a "presença escondida do tema proposto", a variação almeja desvelar criativamente os sentidos de um tema posicionado como questão para a tarefa do pensamento. Ora, o que é dito em contexto teológico não é de modo algum restrito à teologia. Aliás, é preciso dizer que a ideia alvesiana de teologia coloca em xeque algo como a ideia de uma ciência do divino, saber racional acerca do sagrado ou ainda um tipo específico daquilo, que, desde a modernidade ocidental, se chama de ciências humanas. Teologia é variação realizada com as peças de um jogo. É como jogo - e não como racionalidade da fé (intellectus fidę) - que Alves compreende a teologia. Seu caráter de jogo e sua faceta lúdica possuem como sentido o que Schiller chamou de "excesso de vida" (SCHILLER apud in ALVES, 1982, p. 23), ou seja, teologia é jogo lúdico porque não possui sentido explicativo-racional, tampouco pragmático-funcional, mas vital, isto é, seu interesse desinteressado se identifica com a intensificação e expansão da vitalidade, 
sendo esta, portanto, um fim em si mesma. Jogar com os temas, conceitos, símbolos, linguagens etc. de uma determinada tradição religiosa, com a tarefa de produzir potencialização vital - eis o sentido do labor teológico para Rubem Alves. Isso significa que a teologia não tem como missão perscrutar divindades, mas possibilitar modos de vida em meio aos quais a própria vida possa articular a si mesma de modo qualitativamente afirmativo-expansivo. Ora, a relação entre jogo, ludicidade e variação reaparece ao longo dos textos de Alves, ainda quando tais conceitos não são nomeados e questões consideradas academicamente teológicas não aparecem explicitamente. Por esse motivo, é possível se orientar por essa articulação, entendendo-a como horizonte hermenêutico irredutível ao saber teológico.

O objetivo central deste artigo é caracterizar, em linhas gerais, a temporalidade messiânica em Rubem Alves, a partir da articulação de três conceitos nodais de seu caminho de pensamento, a saber, corpo, poder e esperança. O tempo messiânico, como está claro no título deste estudo, é apresentado como entretempo. Tal noção, que não aparece nos escritos alvesianos, funciona, aqui, como hipótese investigativa, segundo a qual $o$ tempo messiânico integra sincronicidade e diacronicidade, o que permite afirmar que a esperança aponta para uma alteridade qualitativa, um futuro qualitativamente outro, porém condicionado (mas, não determinado) pelo caráter sincrônico da história do mundo. Daí a ideia de um entre-tempo, verdadeira encruzilhada que intersecciona sincronicidade e diacronicidade temporais. A relação entre os elementos que compõem o conceito alvesiano de corpo (por exemplo, desejo, afeto, formação político-existencial de sentido e imaginação) e poder formam o eixo conceitual em torno do qual o sentido messiânico da temporalidade se forma. Como a questão da temporalidade messiânica em Alves se manifesta por meio de uma clara simbólica religiosa de matriz judaico-cristã, será necessário operacionalizar alguns conceitos/símbolos dessa tradição. Importa, porém, reforçar que o caminho a seguir realiza com Alves o que ele mesmo entendeu ser uma questão de método: a variação de temas, questões, símbolos e conceitos da tradição. Eis os tópicos que demarcam as etapas deste estudo: 1) Temporalidades do mundo: entre realismo e utopia; 2) Teogonia somatológica: das matrizes corporais das divindades ao sentido político dos corpos divinos; e 3) Corpos messiânicos e alteridades temporais: a lógica do entretempo. 


\section{Temporalidades do mundo: entre realismo e utopia}

O que aqui estamos a chamar de temporalidade messiânica é, simultaneamente, uma experiência humana e mundana. Humana, porque irrompe na e para a condição humana; mundana, porque mobiliza historicamente o mundo, mesmo que o tempo messiânico não se esgote na história. Ora, a articulação de ser humano e mundo requer um questionamento mais radical. Como a temporalidade messiânica pode ser, ao mesmo tempo, humana e mundana? Como se articulam ser humano e mundo? $\mathrm{O}$ que se entende aqui por mundo? Mundo seria o que o medievo latino chamou de ens creatum? A primeira página de Para uma teologia da libertação já deixa claro o sentido originário da relação ser humano-mundo. Alves afirma:

O homem é um ser histórico. Ele não nasce no mundo das coisas, das pessoas e do tempo como um produto acabado. Seu ser não preexiste à história. Torna-se o que é através da história de suas relações com o meio ambiente. Não é, por conseguinte, apenas um ser no mundo: torna-se um ser com o mundo. Homem e mundo não se juntam como duas entidades estranhas que estão eventualmente numa relação de contato, como se fosse uma mente ou um ego que simplesmente notasse aquilo que se lhe contrapõe, ou seja, a matéria. Se assim fosse, o ser humano seria capaz de perceber o mundo; seria capaz de tirar-lhe fotografias tal como uma câmera fotográfica faz. Mas homem e mundo permaneceriam permanentemente estranhos um ao outro. O ser humano não seria capaz de ser penetrado, transformado, criado pelo mundo. E este, igualmente, não se tornaria humanizado. (ALVES, 2019, p. 47)

Para Alves, ser humano e mundo não são instâncias ontologicamente independentes. Em outros termos, a condição humana não é totalizada, tampouco o mundo, seu correlato ontológico. Nesse sentido, o ser humano não nasce como "produto acabado", ou seja, sua condição é marcadamente existencial, no sentido de que o inacabamento, a incompletude ou ainda o estado de abertura marca essencialmente seu ser ( HEIDEGGER, 2006, §9). Sempre em aberto, o ser humano vem a ser quem ele é no mundo e com o mundo. Eis aqui um jogo preposicional de Alves, cuja relevância não pode passar desapercebida. Qual a diferença entre ser no mundo e ser com o mundo? A resposta a essa questão se encontra no autor explicitamente citado mais à frente no texto alvesiano, a saber, Paulo Freire. É dele que Alves retira esse jogo de preposições que marcam a existência humana. Em Pedagogia do oprimido, Freire diz que somos "seres no mundo e com o mundo" (FREIRE, 2013, p. 39). O sentido dessa distinção pode ser 
compreendido à luz de outra consideração: "somos seres condicionados mas não determinados" (FREIRE, 2018, p. 20). Somos condicionados porque o mundo nos atravessa visceralmente, restringe nossas possibilidades e possibilita outras possibilidades. Mas, isso não significa que o mundo nos determine. Condicionar não é determinar. Por isso, nossa relação com o mundo, que Alves adjetivará de dialética, implica pertença ontológica e inadaptação existencial. Por um lado, o mundo nos faz, nos "constrói" e, por isso, somos seus filhos e filhas. Por outro, nós criamos, alteramos, reinventamos o mundo.

Ao dizerem que somos no mundo, Alves e Freire estão se apropriando da noção fenomenológico-existencial de ser-no-mundo, paradigmaticamente presente em Heidegger, mas também em Sartre. Em Heidegger, autor relevante para compreensão da ideia alvasiana de mundo ${ }^{1}$, o mundo é o correlato intencional do ser-aí (Dasein), ente marcado por uma indeterminação ontológica ímpar (poder-ser, Sein-können) e que deve vir a ser ele próprio por meio do desdobramento comportamental de suas possibilidades mundanas de ser. ( HEIDEGGER, 2006, S』 9, 18 e 31) O mundo, por conseguinte, acaba se identificando com a noção de abertura histórica do ente na totalidade, ou seja, o mundo é o horizonte transcendental que condiciona a aparição de todo e qualquer ente e que viabiliza os diversos comportamentos do ser-aí. ( CASANOVA, 2018; CABRAL, 2015) De início e na maioria das vezes, o mundo fornece possibilidades impessoais de ser, o que faz da existência humana uma contínua retomada de medidas ontológico-existenciais homogeneizadoras. (HEIDEGGER, 2006, SS 27, 34-38) Ora, o mundo histórico, fornecedor de sentidos vinculativos e significados dos comportamentos e dos entes

\footnotetext{
É digno de nota que Rubem Alves operacionaliza a ideia fenomenológico de intencionalidade em, no mínimo duas ocasiões importantes. No artigo "Deus morreu Viva Deus!" (1972), em uma crítica explícita a Feuerbach, Alves faz uso do constructo heideggeriano ser-no-mundo, para dizer que o acesso do ser humano a si mesmo só é possível como "homem-em-relação-ao-mundo" (ALVES, 1972, p. 15), o que o leva a mencionar Heidegger em seguida. Ora, como visto, ser-no-mundo é um existencial heideggeriano marcado pela dinâmica da intencionalidade. Isso porque o mundo é o correlato intencional da existência. Em um outro momento, no livro $O$ enigma da religião, ao perscrutar a consciência humana com o objetivo de caracterizar a gênese da experiência religiosa de mundo, Rubem Alves diz claramente: "Consciência é relação. Ela revela sempre uma forma de relação ao mundo.” (ALVES, 1984, p. 56). Em seguida, ele cita uma passagem do livro Phenomenology, de Joseph Kockelmans, que trata exatamente da noção fenomenológica de intencionalidade.
} 
em geral (HEIDEGGER, 2006, \$18), constitui o ser-aí, ainda que ele seja como outros são, isto é, sob a ditadura da impessoalidade. Contudo, esse condicionamento não é uma determinação cabal, uma vez que a indeterminação ontológica do ser-aí não o permite se totalizar, se substancializar ou se reificar. Por isso, no fenômeno existenciário da singularização, o ser-aí vem a ser propriamente quem ele/a é, inscrevendo no mundo uma medida existencial que ele [o mundo] não possui, o que acaba por mobilizar o próprio mundo e, consequentemente, a história. (Cf. CASANOVA, 2009) Essa dinâmica de modulação existencial do ser humano por parte do mundo e de transformação do mundo mediante a singularização do ser-aí reaparece de outro modo na estrutura ser-nomundo-e-com-o-mundo.

Assim como em Freire, para Alves, o mundo é espaço histórico de constituição primária dos seres humanos que nele coabitam. O mundo é, portanto, espaço histórico compartilhado. Por outro lado, não a singularização, mas a práxis transformadora mobiliza o mundo e o faz vir a ser outro. Ora, se não há qualquer instância metafísica que sustente o ser humano e o mundo, então, ambos são ontologicamente histórico-temporais. A mutabilidade humano-mundana deriva, por um lado, do sentido responsivo que constitui a condição humana. Responsividade: ser que responde pela mundanidade do mundo e pelos modos de habitação no mundo. O ser humano não é, portanto, um ser que é obrigado a reagir ao mundo, no sentido meramente biológico de reação; ele pode responder criativamente ao mundo. Como afirma Alves: "O homem se modifica por não ser uma mônada: ele é abertura. Por ser aberto, é capaz de responder, ao invés de simplesmente reagir. O reagir é um ato que se localiza na esfera do biológico. O responder, contudo, pertence à esfera do liberdade" (ALVES, 2019, p. 48). A responsividade acaba se identificando com o exercício da liberdade e a liberdade se identifica com a atividade criadora. Rubem Alves não pensa a liberdade como livre-arbítrio, tampouco como a priori ontológico. Liberdade é tarefa, cujo sentido se revela como transformação histórica do mundo.

A mundanidade do mundo não se esgota no seu sentido histórico. Alves inscreve no conceito de mundo a questão da linguagem. O mundo é atravessado pela linguagem humana. Por um lado, a linguagem aparece como “espelho de sua [do ser humano] historicidade" (ALVES, 2019). Dessa forma, a linguagem não se reduz ao caráter pretensamente especular das ciências modernas, que visam espelhar de forma "neutra" e objetiva os fenômenos 
mundanos em geral. Ela se funda no sentido responsivo da condição humana. Dessa forma, a linguagem assinala um complexo processo de interpretação humana do mundo. Essa interpretação (formação de sentido) é a resposta humana "às situações concretas nas quais o homem se encontra" (ALVES, 2019). Interpretar, nesse caso, é criar possibilidades humanas de habitação de mundo, significar experiências e direcionar o mundo e a existência humana no mundo. Como Alves afirma em Variações sobre a vida e a morte (1982, p. 86): "Palavras: coisas. Estórias: estruturas concretas construídas como palavrascoisas, que jogamos no mundo. E, uma vez lançadas no mundo, estas coisas - se verdadeiras ou não, é irrelevante - fazem o mundo diferente."

Ainda que a linguagem assinale, originariamente, uma experiência humana de mundo e a autocompreensão humana que se manifesta por meio desta experiência - "O aparecimento de uma nova linguagem anuncia, por conseguinte, o nascimento de uma nova experiência, de uma nova autocompreensão, uma nova vocação e, consequentemente, de um homem e de uma comunidade diferentes" (ALVES, 2019, p. 49). -, palavras e "estórias" atuam transformacionalmente no mundo. Eis o sentido poético-criador da linguagem, segundo Alves. Não há, portanto, transformações humanas e mundanas que não manifestem novas linguagens. Ora, se linguagem, mundo e ser humano se vinculam essencialmente, isso não significa dizer que todos os mundos, todos os tipos de seres humanos (modos de ser) e todas as linguagens se equivalem. Se levarmos em conta a ideia de "proletariado mundial"' (ALVES, 2019, p. 50) como nova forma de comunidade desejada e cobiçada ao longo de parte da segunda metade do século XX, fica claro que Alves entende que as comunidades, os mundos e as linguagens são qualitativamente diferenciados. Em certo sentido, há mundos, formas humanas de habitar o mundo e linguagens que se constituem mediante o abandono de seu caráter histórico-temporal. Nesse caso, o ser humano, sua linguagem e seu mundo tendem à absolutização, à imutabilidade, à calcificação. O sentido qualitativo dessa forma de temporalização do mundo, do ser humano e da linguagem é, segundo Alves, a opressão. A temporalidade está, nesse caso, refém da manutenção do status quo opressivo. Assim, agir é reproduzir o que já é. A abertura criadora dos seres humanos se engessa e a criação se torna tão-somente adaptação. Eis o significado alvesiano do conceito de realismo, que atravessa mas não se reduz ao âmbito epistemológico.

Por realismo, Alves entende uma forma específica de construção histórica do ser humano e do mundo. É que a noção de mundo, em verdade, 
é uma "construção social" (ALVES, 1987, p. 56) e o ser humano, por ser no mundo, é, inicialmente, efeito dessa construção. Ora, a ideia de realidade deriva dessa construção. A realidade não se identifica com a noção de objeto; a noção de objeto só possui sentido no interior de certa construção (moderna) social. Dessa forma, o realismo é uma ideologia cujo sentido é perpetuar uma determinada construção social. (ALVES, 1987, p. 60) Somente na sociedade ocidental moderna, pragmatismo, cientificismo, positivismo, tecnologia e etc. fazem sentido e, por isso, servem à estabilização e perpetuação dessa mesma construção social. A temporalidade do realismo é, por conseguinte, o movimento de automanutenção do status quo do tipo de formação social moderna ocidental. Não é preciso lembrar a multiplicidade de formas de opressão que atravessa e condiciona esse tipo de formação de mundo. Por isso, a temporalidade do realismo social (também epistemológico, moral, religioso etc.) estabiliza os modos modernos de construção social e, assim, legitima e naturaliza opressões diversas.

A naturalização das construções sociais não consegue absolutizar o mundo, ainda que as ideologias o queiram, pois somos seres com o mundo, isto é, seres destotalizados e incompletos. Essa inadequação ontológico-existencial incide diretamente em nossa forma de habitação no mundo. Disso decorre a apropriação alvesiana da ideia de Camus, segundo a qual a consciência nasce com a revolta, isto é, com a recusa da realidade injusta e opressora tal qual ela atualmente é. (ALVES, 2006, p. 49) Em outras palavras, a existência humana se revela em sua constituição ontológica mediante a inadaptação à construção social do mundo em que está enredada. Na revolta, o ser humano afirma outra possibilidade de existência, ao mesmo tempo que afirma outras formas possíveis de o mundo se estabelecer historicamente. Exatamente nessa inadaptação se revela outra temporalidade do ser humano e do mundo. Trata-se do que chamaremos de temporalidade utópica. A temporalidade utópica nasce de uma experiência ímpar, que, em Alves, atravessa uma diversidade de experiências, sobretudo religiosas, a saber, aquela que afirma que o possivel é maior que o real. Dito de outra forma, as utopias suspeitam que "os limites do possível sejam muito mais extensos que os limites do real" (ALVES, 2006 p. 46-47) - ou seja, toda utopia "liberta o homem do determinismo das forças materiais que criam compulsão do comportamento de fuga" (ALVES, 1987, p. 120). A temporalidade que aí se estabelece assinala uma outra qualidade do ser humano (novos modos de ser) e do mundo. Trata-se, portanto, de um movimento de futuração de uma nova qualidade do mundo e da existência 
humana. Por um lado, essa temporalidade é uma contratemporalidade, uma vez que ela só acontece negando, rejeitando a temporalidade do realismo. Por outro, a temporalidade utópica se identifica com o acontecimento criador e não adaptativo de comportamentos e ações subversivos. A temporalidade utópica é a temporalidade da resistência, da possibilidade de negar para criar - temporalidade da liberdade.

\section{Teogonia somatológica: das matrizes corporais das divindades ao sentido político dos corpos divinos}

A temporalidade utópica, que se relaciona com o entretempo messiânico, pode ser radicalizada e mais bem compreendida, se levarmos em conta os elementos conceituais que estruturam o corpo e a possibilidade deste apresentar-se como corpo-criação, ou seja, como índice de liberdade. Ora, em Alves, a relação entre corpo e criação se revela plenamente na teogonia ou ainda no fenômeno da consciência religiosa. Por isso, devemos, agora, caracterizar o que estamos a chamar de teogonia somatológica, pois nela é possível abrir uma porta de entrada que articula a temporalidade utópica e o entretempo messiânico. Ao estudar o fenômeno religioso, Alves se depara com a dificuldade de reduzi-lo ao plano da objetividade dos fenômenos estudados pelas ciências naturais e sociais modernas. Fenômenos religiosos derivam da consciência religiosa e esta não pode ser compreendida segundo o método de Durkheim, que considera tais realidades "como se fossem coisas" (ALVES, 2006, p. 38). É que "a essência da religião não é um objeto, mas uma relação” (ALVES, 2006, p. 39). Exatamente o sentido dessa relação aponta para a teogonia somatológica. Por um lado, a consciência religiosa parteja divindades: teogonia. Por outro, a consciência religiosa não se identifica com uma mente descorporificada, presente num espírito sem corpo. A consciência religiosa é uma articulação do corpo que somos. Por isso, as divindades que nascem da consciência religiosa, em verdade, nascem do corpo. Daí a teogonia ser uma somatologia. Ora, como isso é possível? O que significa, nesse caso, corpo? E divindade? Vejamos.

Comecemos pela questão: como é possível correlacionar corpo e divindade? Resposta: por meio da assunção da morte de Deus. Sim, o caminho de pensamento de Rubem Alves passa pelo "esmeril hermenêutico" da morte de Deus. Falamos em esmeril hermenêutico porque a morte de Deus descerra um horizonte hermenêutico irredutível os modos de ser e pensar hegemônicos das tradições ocidentais. A presença da morte de Deus em Alves pode ser 
vista em diversos textos e contextos de seu pensamento. Já o título de um conhecido texto seu de 1972, "Deus morreu - Viva Deus!", deixa isso claro. O que parece uma contradição, o fato de se celebrar a presença de Deus por meio de sua morte, é, em verdade, um paradoxo assumido por Alves. Paradoxo, no sentido operacionalizado por Kierkegaard: a copertinência de elementos que a tradição metafísica ocidental sempre considerou lógica e/ou ontologicamente opostos e contraditórios. Afirmar Deus em meio à sua morte não é uma contradição, é uma possibilidade hermenêutica nascida da derrocada do teísmo metafísico, um dos grandes efeitos hermenêuticos da própria morte de Deus. Não só isso. A morte de Deus suprime o que parece ser o contrário do teísmo, a saber, o ateísmo. Em verdade, para Alves, o ateísmo é a outra face da moeda do teísmo. Nas suas palavras: "Teísmo, como afirmação da existência do ente Deus, e ateísmo como sua negação, na realidade, são duas expressões de uma mesma visão de mundo" (ALVES, 1972, p. 14). Ora, a morte de Deus é a morte de uma compreensão específica de mundo, uma vez que o significante Deus nasce de uma relação humana com o mundo, não se resumindo a significar o mais ente dos entes (ente supremo), aquele metafisicamente superior aos demais. Para Alves, Deus é um signo linguístico que nasce de um modo de relação ser humano-mundo. Por isso, sua morte assinala a morte de uma experiência histórica do mundo. Em síntese:

Se hoje se anuncia que Deus morreu, temos de nos lembrar de que ele nasceu. Nasceu como parte da história do homem, como símbolo linguístico do seu universo de interpretação de suas relações com o mundo. Sua morte, portanto, é um outro evento - não na história de Deus! - mas na história do homem. Foi o homem que mudou. Agora, defronta-se com o seu mundo de uma forma diferente. Uma nova problemática - uma nova interpretação. E com isso, o envelhecimento das velhas interpretações, problemas e palavras. É por isso que "Deus", como símbolo particular de uma interpretação, envelheceu e morreu. Mas é preciso que não façamos o erro de ver nisso um fenômeno teológico. Trata-se de um fenômeno humano. Quem morreu não foi Deus, mas o homem que foi capaz de usar esta palavra para orientar-se no mundo. (...) Entender a morte de Deus, é, por isso mesmo, compreender o novo homem que está nascendo. (ALVES, 1972, p. 18)

Alves compreende a morte de Deus como colapso de uma cosmovisão e dos modos de ser correlatos à cosmovisão em questão. Porém, isso não é tudo. Ao caracterizar que mundo foi esse abalado com a morte de Deus e que tipo de ser humano se tornou inviável com tal colapso, Alves diz: 
“Aqui o símbolo 'Deus' é inseparável de um universo ordenado e vertical, em cujo topo se encontrava o Ancião Eterno, de olhar severo, como representava a arte contemporânea". (ALVES, 1972, p. 19-20) Trata-se de uma entidade metafísica, que habitava até então a transcendência do âmbito suprassensível, como pensou a tradição platônica como um todo. Ora, a irrupção da modernidade ocidental e seu afã por afirmação do ser humano como índice de significação do real não serão compreendidos por Alves como acontecimentos afirmativos e criadores. $\mathrm{O}$ antropocentrismo moderno e sua atuação tentacular por meio da tecnociência não comovem Alves. Isso possibilita dizer que os efeitos hermenêuticos da morte de Deus, como foram pensados por Nietzsche, são de alguma forma assumidos por Alves. Dito de modo resumido, a morte de Deus em Nietzsche, apesar das suas várias formulações e de seu caráter polissêmico, assinala um acontecimento histórico decisivo. Após mostrar o sentido catastrófico da morte de Deus por meio da imagem parabólica de um homem louco/insensato (der Tolle Mensch) na passagem 'Para onde foi Deus?', gritou ele [o louco/insensato]: 'já lhes direi! Nós o matamos - você e eu. Somos 'todos seus assassinos!' Mas como fizemos isso? Como conseguimos esvaziar o mar? Quem nos deu a esponja para apagar o horizonte? Que fizemos nós, ao desatar a terra de seu sol?" (NIETZSCHE, 2002, \$125), Nietzsche diz: "Nunca houve um ato maior - e quem vier depois de nós pertence por causa deste ato a uma história mais elevada do que toda história até aqui!" (NIETZSCHE, 2002, §125) O assassinato de Deus (deicídio) é o ato mais decisivo da história ocidental. Por quê? Porque Nietzsche entende o significante "Deus" como qualquer instância metaempírica, que funcione como valor supremo dos comportamentos humanos e/ou como princípio absoluto de inteligibilidade do real (CASANOVA, 2003; CABRAL, 2014). Dessa forma, Deus sustenta toda e qualquer compreensão binária de mundo, que cinde e hierarquiza duas instâncias ontológicas distintas, o sensível e o suprassensível, que se expressam historicamente como eternidade/tempo, uno/múltiplo, substância/acidente etc. Tal hierarquia ontológica está associada a uma interpretação moral de mundo, uma vez que o plano-Deus (suprassensível) se identifica com o bem e a outra instância, se for autonomizada, se revela como o mal. A morte de Deus colapsa os binarismos metafísicos e as interpretações morais de mundo. Essa dissolução hermenêutica é, de alguma forma, assumida por Rubem Alves.

Já a ideia alvesiana segundo a qual o significante "Deus" nasce de uma articulação histórica da relação originária ser humano-mundo é um claro sinal 
de que seu pensamento se move em um regime discursivo não metafísico. Ora, um dos binarismos metafísicos que será ressignificado por Alves possui matriz antropológica, a saber, a dicotomia corpo e alma. Na hierarquia metafísico-antropológica tradicional, a alma aparece como fundamento ontológico do corpo. Daí a suposta superioridade epistemológico-moral da alma, sendo esta decisiva para uma miríade de práticas e discursos cristãos. Entretanto, ressignificar não metafisicamente a condição humana não equivale a abandonar as palavras utilizadas por esta tradição, como liberdade, corpo, alma, intelecto, verdade, desejo etc. Pensamentos que não são condicionados por regimes discursivos metafísicos podem, vez por outra, transformar palavras tradicionais em conceitos não metafísicos. É o caso da noção alvesiana de corpo e dos termos que funcionam como notas deste conceito, como desejo e imaginação, por exemplo. Isso fica claro quando Alves assume uma passagem decisiva de Nietzsche, presente em Assim falou Zaratustra:

"Eu sou corpo e alma" - assim fala a criança. E por que não se deveria falar como as crianças?

Mas o homem já desperto, o sabedor, diz: "Eu sou todo corpo e nada além disso; e alma é somente uma palavra para alguma coisa no corpo".

O corpo é a grande razão, uma multiplicidade com um único sentido, uma guerra e uma paz, um rebanho e um pastor.

Instrumento de teu corpo é, também, a tua pequena razão, meu irmão, à qual chamas "espírito", pequeno instrumento e brinquedo da tua grande razão.

"E", dizes e ufanas-te desta palavra. Mas ainda maior, no que não queres acreditar - é o teu corpo e a sua grande razão: esta não diz eu, mas faz o eu. (NIETZSCHE, 2003, I, "Dos desprezadores do corpo”; ALVES, 1982, p. 35)

Ao dizer com Nietzsche que o ser humano é corpo, Alves não entende a corporeidade metafisicamente, ou seja, ele não inverte a relação tradicional entre corpo e alma, pois não posiciona o corpo no lugar da alma e a alma no lugar do corpo, preservando, assim, os velhos lugares hierárquicos criados pela tradição metafísica. É por esse motivo que Alves não pensa o corpo biologicamente; não supõem, portanto, uma natureza corporal no ser humano. É ele mesmo quem diz: "O ser humano não é uma entidade da natureza. (...) Não mais estamos à mercê da programação biológica. Movemo-nos na rede cultural que lançamos". (ALVES, 1982, p. 46) Em outros termos, nosso corpo é mundano, histórico, cultural, ou seja, somos corpo-linguagem. É possível afirmar, então, que, originariamente, o corpo não é uma substância, nem um substantivo, mas um verbo: corporificar, tornar-se corpo, vir-a-ser corpo. Dito 
de outra forma: "O homem não está programado pelo seu corpo. Sua vida pregressa não o torna cativo. (...) Seu corpo é criativo”. (ALVES, 1987, p. 164) O devir corporal, contudo, está ancorado no movimento produtor de futuro e no horizonte de futuro criado pelo próprio corpo. A produção do horizonte de futuro criado pelo corpo deriva, segundo Alves, da imaginação; já ao movimento de criação de futuro, ele chama de desejo. Corpo, desejo e imaginação se interpenetram essencialmente. Somente por esse motivo o corpo se faz corpo-criação.

Se corpo, desejo e imaginação se pertencem, então, é possível afirmar que o ser humano é um corpo imaginativo. A imaginação nasce da recusa de aceitar como palavra final o status quo. O mundo como está sendo não pode ter a palavra final. Não enxergando ponto final, a imaginação inventa as reticências. Por isso, injeta o possível em meio ao real. Para que isso seja possível, a imaginação deve negar o que é e transcendê-lo de algum modo. Porém, para Alves, isso não acontece aleatoriamente. Importa-lhe articular imaginação e insatisfação, o que se revela plenamente na experiência do sofrimento humano: "a imaginação surge da insatisfação do homem com a realidade existente". (ALVES, 1987, p. 47) Ora, a imaginação atua através do desejo, esse ímpeto corporal que move o ser humano para além de si, rumo ao que lhe falta. Mas, o que falta ao ser humano? O que almeja o ser humano por meio da sua imaginação desejante? Para Alves, o sentido do desejo não se reduz à transitividade das relações entre sujeito e objeto desejado, ainda que, vez por outra, esse aspecto do desejo apareça em seus textos. O sentido do desejo se revela sobretudo em um âmbito qualitativamente novo, marcado pela superação das opressões que se naturalizam historicamente no mundo. "O corpo humano criou para si mesmo a possibilidade de deixar para trás um passado que tenha se mostrado disfuncional e opressivo e isto, por conseguinte, torna possível a ele agir sob a inspiração de suas intenções." (ALVES, 1987, p. 167) O sofrimento decorrente da opressão é a condição para a irrupção do desejo por um mundo qualitativamente diferente e por um ser humano livre das amarras da injustiça e livre para o movimento autocriador da existência. O sentido originário do desejo, portanto, é a criação qualitativa e não a falta quantitativa.

O que foi dito ainda não dá conta da teogonia somatológica de Rubem Alves. Por um lado, ainda não tocamos no tema da teogonia. Por outro, mostramos o sentido político do corpo. Comecemos por esta última questão. Se o corpo não se reduz ao corpo biológico tal qual o 
conhecemos mediante os discursos biomédicos desde o século XIX, isso se deve ao fato de o seu caráter verbal inscrevê-lo inteiramente no mundo, na história. Ora, se o mundo se identifica com a noção de construção social e se esta construção está quase sempre eivada de injustiças e opressões, então, o corpo é condicionado pela estruturação política do mundo. Isso porque a política responde pela regulação dos corpos humanos no mundo. Exatamente por isso, Alves leva em conta o conceito de poder, para pensar o sentido político da corporeidade. Em uma das poucas vezes que Alves caracteriza sua compreensão do poder, ele diz: "O poder, como vimos, cria a organização, e esta é a base e a origem política de nosso mundo”. (ALVES, 1987, p. 71) Segundo essa caracterização, o poder "cria a organização", o que equivale a dizer que o poder cria modos de organização do mundo. Ele cria possibilidades e restringe outras; ele produz modos de compreensão da realidade, o que o conecta com a linguagem (ALVES, 1987, p. 56). Antes do poder ser opressor, ele é configurador de realidade histórica. Por isso, somente compreendendo como o poder organiza a sociedade é possível entender o seu sentido opressor. Entretanto, o poder não há. Alves não pensa o poder de modo essencialista. Antes, o que existe são exercícios de poder, que incidem diretamente na qualidade de vida dos corpos em que eles atuam. Melhor:

O mesmo poder que faz corpos dançar e sorrir é o poder que faz corpos se contorcer e gritar. O poder pode ser divino ou demoníaco, pode libertar ou escravizar, dar vida ou matar. Do poder nascem universos, as estéreis dão a luz, vales de ossos secos se levantam como exércitos, a virgem fica grávida, os cegos e leprosos ficam curados, os mortos são ressuscitados, céus e terra se transformam. Mas com o poder nasce o orgulho, a opressão, Herodes matando crianças, o império romano crucificando o Filho de Deus. (ALVES, 1984, p. 55)

Corpo e poder se interpenetram; corpo e política se pertencem. Dito de outro modo, não há corpo que não seja investido politicamente pelo poder. Por isso, falamos em corpoder ou corpolítica. Ora, é desse corpo que nascem desejos por mundos outros e por outros modos de ser humano. Como esses corpos insatisfeitos que desejam e imaginam qualidades de ser afirmativas sofrem dores de opressão, é a partir dessa corporeidade que Alves se interessa por pensar o nascimento das divindades (teogonia). O sentido de ser dos Deuses e Deusas está fincado nos corpos dos quais eles e elas nascem. A vida, portanto, se engravida de divindades. Duas questões 
surgem daí: em que tipos de vida nascem as divindades? Quais qualidades de corpo e de mundo estão em jogo nas divindades? Seguindo uma intuição profética, há Deuses ou Deusas que legitimam a opressão e a injustiça: são os ídolos religiosos, que justificam o poder hegemônico. Porém, há divindades que nascem dos desejos corporais de liberdade e plenitude de vida. ( ALVES, 2014, pp. 101-111) Essas divindades afirmam o poder do amor e a beleza como sentido último do poder. Todavia, as divindades dos corpos injustiçados estão atreladas à impotência desses mesmos corpos, uma vez que aquilo que estes desejam quase nunca encontra condições políticas para sua realização e implementação.

Quando Alves afirma que "a consciência religiosa é uma expressão da imaginação" (ALVES, 1987, p. 42), ele está co-dizendo que o sentido dos símbolos religiosos, inclusive dos Deuses e Deusas, só se revela, se considerarmos o sentido corporal da imaginação; ou melhor, em forma de pergunta: de que tipo (qualidade) corporal nasce tal desejo que conduz tal exercício da imaginação? As divindades possuem, por conseguinte, qualidades corporais. Elas ganham corpo, corporificam o sentido do corpo humano através do qual surgiram. Esse corpo deseja uma qualidade de vida que não encontra espaço na atual constituição histórica do mundo. Por isso, nele fala um novo jogo de possibilidades do mundo e do ser humano. Melhor: nele fala uma nova política, um novo poder, no qual o corpo encontra a possibilidade de afirmar-se em seu horizonte criador mais pleno. Ao discutir a relevância do pensamento de Feuerbach, por exemplo, Alves mostra que os símbolos religiosos não são simples projeções da natureza humana representada pela subjetividade dos indivíduos humanos. Antes, como visto, o ser humano não possui essências metafísicas. Dessa forma, os símbolos religiosos falam de possibilidades humanas de habitar o mundo. Ora, nos corpos impotentes oprimidos, irrompem divindades cujos significados se revelam nos desejos de transformação qualitativa do ser humano e do mundo. Levando isso em consideração, deve-se dizer que "Nas aspirações do homem oprimido" (ALVES, 1982, p. 50), se revela o significado afirmativo dos atributos divinos. Caso contrário, estaremos supondo um significado absoluto das divindades e justificando, assim, as divindades que legitimam o status quo opressor. Destarte, o que estamos a chamar de teogonia somatológica revela seu significado no sentido político dos corpos humanos e dos corpos divinos. 


\section{Corpos messiânicos e alteridades temporais: a lógica do entretempo}

A temporalidade messiânica acontece através de corpos messiânicos. É que a temporalidade se revela, no caso do pensamento de Rubem Alves aqui operacionalizado, como tempo mundano-corporal. Nesse caso, a temporalidade é marcada por decisões e cisões qualitativas do corpoder que somos. As descontinuidades qualitativas assinalam o desejo por interrupção de experiências históricas que inviabilizam as possibilidades criadoras da condição humana. Foi nesse sentido que Alves, em sua tese doutoral, de forma categórica, assume a nova consciência que, nas décadas de 1950 e 1960, estava surgindo em grande parte do mundo: Estados Unidos (movimento estudantil e movimento antirracista de luta pelos direitos civis), movimento anticolonialista (libertação da Argélia, obra de Franz Fanon), maio de 1968, lutas por libertação revolucionária na América Latina etc. Dessa consciência, chamada por ele de consciência proletária, surge a interpretação segundo a qual o presente deve ser negado porque ele nega o ser humano por meio de diversas opressões. Tal realidade identifica sofrimento com injustiça e estes, segundo Alves, obstaculizam a possibilidade do futuro. A consciência proletária nega, portanto, a história em prol da história.

Tal consciência nega a história em nome da história e a partir do próprio interior da história. O presente é negado porque o homem, vivendo nela, apreende tudo aquilo que cria a dor, o sofrimento, a injustiça e a ausência de futuro na história. Devido ao presente ser historicamente doloroso e, portanto, desumanizante, ele tem de ser negado." (ALVES, 2019, p. 62)

É a desumanização da condição humana que está em questão para Alves. As condições políticas do corpoder que somos assumem formas de opressão, que nos impedem de exercer a nossa existência de modo pleno e livre. Negar o que nos nega é a única possibilidade de retemporalizar nossos corpos. Caso contrário, o que chamamos de futuro será tão-somente a retomada e a repaginação da qualidade opressora do presente. Sem a criação de alteridades temporais, sem a produção de um outro tempo, a saber, o tempo do qualitativamente outro, a história perde seu sentido.

O que estamos aqui a chamar de tempo messiânico se identifica, em verdade, com um outro tempo. Na verdade, esse outro tempo é o tempo do outro. Essa alteridade, porém, não se resume ao outro compreendido como alguém ou alguma pessoa, mas à superação da qualidade oprimida, 
reprimida, negada, recusada pelas políticas de destruição da liberdade. Em outras palavras, a alteridade do tempo e o tempo da alteridade são irredutíveis à temporalidade da injustiça, que rouba da existência o sentido criador do tempo. A alteridade, nesse caso, nada mais é que a qualidade afirmativa de vida inexistente em condições de opressão. Ora, essa temporalidade da alteridade só é possível como esperança, experiência que, na compreensão de Alves, nada tem de a-histórica. Nas suas palavras: "A esperança não se deriva de uma ideia a-histórica a respeito de uma sociedade perfeita; ela constitui, ao contrário, a forma positiva assumida pela negação do presente inumano e negativo". (ALVES, 2019, p. 62) A esperança, portanto, é potência mobilizadora das transformações qualitativas da história, uma vez que afirma possibilidades outras de ser, que contrastam com a normatividade da opressão e da injustiça. Disso surgem duas possibilidades de se pensar e exercer a esperança, a saber: a) a esperança pode ser concebida e exercida por meio da ideia de que as mudanças qualitativas da história se dão através dos seres humanos e unicamente causadas pelos seres humanos; e b) a esperança pode ser compreendida como atividade desempenhada pelos seres humanos, porém sem que se resuma tão-somente às capacidades humanas de mobilização causal do mundo. Essas “duas” esperanças só se identificam formalmente. Suas diferenças materiais são, por outro lado, abundantes.

A esperança reduzida unicamente à força transformadora do ser humano foi caracterizada por Alves como um tipo específico de messianismo: o "messianismo humanista". (ALVES, 2019, p. 64) O seu caráter humanista diz respeito à busca contínua por humanização de um mundo desumanizado. Já a sua faceta messiânica aparece por meio da ideia de que o futuro criado unicamente pelas mãos humanas é o índice de liberdade e libertação. Apesar da relevância desse messianismo, Alves percebe nele elementos indesejáveis e até perigosos. Primeiramente, esse tipo de humanismo político "constitui uma forma de otimismo histórico”. (ALVES, 2019, p. 146) Ora, a diferença entre otimismo e esperança será explorada em diversos textos alvesianos. Uma delas aparece já em Variações sobre a vida e a morte, quando Alves mostra que há políticas vitoriosas que acontecem através da "lógica dos porquês e dos em decorrência de." (ALVES, 1982, p. 69), enquanto há uma lógica "que se resume na expressão a despeito de." (Ibidem, p. 68) Nesse sentido, o otimismo histórico do messianismo humanista acredita nas circunstâncias favoráveis e na força causal das ações humanas. Trata-se, no mínimo, de uma ingenuidade, pois a história não se resume ao jogo da causalidade. Como mostrou Hannah 
Arendt: "A causalidade é entretanto uma categoria totalmente estranha e falseadora no que diz respeito às ciências históricas. Não só é verdade que o real significado de todo evento transcende qualquer número de causas passadas que possamos atribuir a ele (...), mas também que o próprio passado só vem a ser com o próprio acontecimento". (ARENDT, 1993, p. 49) E se as situações inviabilizarem a gestação de um futuro qualitativamente libertador? E quando os seres humanos não conseguem, tão-somente por meio de suas próprias forças, transformar a história? Para Alves, isso leva o messianismo humanista a dois destinos possíveis: ao romantismo, entendido como afirmação do futuro por meio da cegueira humana em relação às forças concretas e contraditórias da história, e ao cinismo, este compreendido como o abandono da esperança que resulta da frustração humana diante da incapacidade de modificar a história (ALVES, 2019, p. 147). Por isso, ainda que a esperança implique o ser humano por inteiro em ações transformadoras da história, ela não pode se resumir à horizontalidade das forças históricas, nem mesmo à ilusão da onipotência das ações humanas. A possibilitação das possibilidade transformadoras é, em última instância, de outra ordem: não é filha da causalidade e/ou probabilidade, mas da gratuidade. Esperança e gratuidade, e não esperança e causalidade - eis o par alvesiano.

No lugar do messianismo humanista, Alves pensa o humanismo messiânico. O humanismo messiânico compreende a possibilidade do futuro transformador como dádiva. O futuro acontece por meio das ações humanas, mas não somente por causa das ações humanas. Para dar conta da caracterização desse paradoxo, Alves operacionaliza a linguagem bíblica e a experiência histórica que a condiciona. Por exemplo, a libertação do cativeiro do Egito narrado sobretudo no livro bíblico do Exxodo não decorreu dos dados objetivos das situações ali descritas. Nesse caso, o povo de Israel "não se fez livre: foi obrigado a ser livre" (ALVES, 2019, p. 150). Isso significa que as possibilidades de libertação não decorreram da situação em que se encontrava Israel, mas foi doada gratuitamente, a despeito do status quo. Daí a especificidade da linguagem do humanismo messiânico: "A linguagem do humanismo messiânico não é mais que uma expressão dessa experiência histórica de liberdade e libertação 'apesar de', quando todas as possibilidades subjetivas e objetivas de liberdade, imanentes da história, haviam sido abortadas" (ALVES, 2019). A despeito de..., apesar de... - eis o modo como a possibilidade da libertação acontece historicamente, na vida dos corpos oprimidos. A libertação não nega a ação, mas sua possibilidade 
não decorre da ação. Repetindo o que fora dito: a libertação (futuro) se dá por meio da ação transformadora, mas não por causa da ação transformadora. Eis como a esperança atua: a partir da dádiva das possibilidades históricas de libertação. Melhor:

)Todo nosso jogo das contas de vidro [a teologia] depende de nossa capacidade para articular a estranha lógica que se constrói em cima desta esperança. Não sei bem. Talvez o oposto seja a verdade, e seja a esperança messiânica que nasce dessa lógica...

Lógica que se resume na expressão a despeito de.

Os teólogos lhe deram o nome de graça. As explicações são difíceis, mas as imagens são claras:

... a estéril engravida,

os mortos ressuscitam,

os velhos ficam crianças,

a virgem dá à luz,

do nada surgem universos... (ALVES, 1982, p. 68)

A esperança messiânica nasce da gratuidade do a despeito de. Por um lado, tal esperança, que nasce dos corpos fracos, oprimidos e injustiçados, integra a descontinuidade temporal, a gênese do tempo da alteridade e a gratuidade. Tal temporalidade nasce em contraposição ao passado, mas se relaciona com esse passado do qual se distingue. Por outro lado, essa temporalidade (utópica) messiânica não é causada pelo passado, nem mesmo pelo presente. A temporalidade messiânica não pode ser caracterizada pelo conceito de causalidade. Ela acontece a despeito de. Trata-se de um acontecimento que implica a ação humana: o povo de Israel marchou do Egito, passando pelo deserto, em direção à terra prometida, segundo o exemplo bíblico. Porém, a possibilidade da libertação do Egito se deu gratuitamente. Nesse caso, "Deus é o nome que se dá à presença do futuro. Ele é a liberdade na história, que faz transcender sua forma presente em direção a uma possibilidade de libertação humana”. (ALVES, 2019, p. 156) A temporalidade do futuro messiânico possui relação com o passado, mas não se expressa como integração de passado, presente e porvir. (Cf. HEIDEGGER, 2006, S 62) Ao mesmo tempo, o futuro messiânico assinala a alteridade qualitativa, porém esta só pode ser afirmada por meio de uma relação de recusa criadora com o presente e com o passado. O totalmente novo se relaciona com o que se tornou velho por meio dessa negação criativa. Por fim, essa temporalidade é gratuitamente possibilitada por uma instância que 
excede aos limites atuais da história. O entrecruzamento desse excesso com a horizontalidade da história forma a temporalidade messiânica. É desse excesso que a relação sincrônica de passado, presente e futuro se casa com o sentido diacrônico do tempo futuro entendido como temporalidade do outro e como outro tempo. O nome Deus, nesse sentido, assinala a possibilidade de o reino da possibilidade de libertação articular, mas sem anular, a temporalidade sincrônica e a temporalidade diacrônica, de tal forma que devemos sempre nos relacionar com o presente e o passado, mas sem que sejamos reféns de seus limites intrínsecos. Ao mesmo tempo, estamos abertos/as à novidade qualitativa do futuro messiânico-libertador, mas sem que saiamos da história: palco em que a humanidade sonha e luta pelas suas possibilidades mais belas de existência. Esse é o sentido da noção de entretempo da temporalidade messiânica: entre temporalidades distintas, sincronicidade e diacronicidade.

É na dádiva do excesso chamado Deus que o corpo impotente se empodera das possibilidades de liberdade que o passado e o presente não legaram. Eis o sentido paradoxal do empoderamento dos corpo impotentes. Esse paradoxo se chama esperança.

\section{Conclusão}

Este artigo teve como objetivo apresentar o conceito de temporalidade messiânica em Rubem Alves, a partir da articulação da tríade tão cara à sua antropologia teológica: corpo, poder e esperança. A temporalidade messiânica, que nomeamos também de entretempo, é marcada pela integração do caráter sincrônico dos acontecimentos condicionantes - mas não determinantes - da história do mundo e do caráter diacrônico de uma esperança que aponta para alteridades qualitativamente outras desta mesma história. Não um outro mundo, mas um mundo outro. Duas temporalidades do mundo se destacam, quais sejam as do realismo e da utopia. Rubem Alves ancora sua temporalidade messiânica no horizonte utópico e, criticando fortemente o realismo, aponta para o reino do possível, como sendo muito maior que o registro do real. A temporalidade messiânica do entretempo alvesiano tem como pano de fundo uma teogonia somatológica. Os Deuses e Deusas são filhos e filhas do suspiro de corpos humanos oprimidos.

A consciência religiosa, partejadora de divindades, é expressão do corpo que somos. Ou seja, as divindades nascem no berço do corpo humano. As teogonias são sempre somatológicas, somatoformes. Vimos como o trincamento à raiz do teísmo metafisico, trazido pelo esmeril da morte de 
Deus, fez reluzir com mais força a relação corpo e divindade no percurso de Rubem Alves. As divindades revelam as modulações qualitativas das formas humanas de habitação no mundo. Dos corpos humanos, forjadores de horizontes pela imaginação e criadores de mundos pelo desejo, nascem e morrem as divindades. O corpo imaginativo e desejante recusa o real que oprime e injeta o possível em suas veias, para superar opressões naturalizadas. Nesta recusa, Rubem Alves localizou o berço das teogonias e voltou seus esforços para pensá-las. Ou seja, os sentido das Deusas e Deuses está fincado nos corpos humanos engravidadores de divindades. De um lado as divindades mantenedoras do status quo, nascidas de corpos legitimadores do poder hegemônico. De outro as divindades nascidas da liberdade e da plenitude de corpos impotentes, que pronunciam o nome sagrado do fundo de suas dores e opressões. Portanto a temporalidade messiânica nasce de corpos messiânicos que desejam superar registros opressivos, regidos por politicas destruidoras do ato criativo humano. Corpos para os quais a alteridade do tempo e o tempo da alteridade não se reduzem ao tempo da injustiça que rouba da existência o seu sentido criador.

Por fim, vimos como o entretempo messiânico em Rubem Alves, por todas as razoes aqui apontadas, se nutre de uma esperança que nada tem de a-histórica. Ao contrário, trata-se de uma esperança nascida do e no interior do acontecer histórico, do e no movimento humano de negação do inumano que nega a vida; trata-se de uma potência de transformações qualitativas da história. Entretanto, tal esperança transformadora não se limita aos poderes humanos de mobilização causal do mundo. Ainda que a esperança implique o ser humano todo no fluxo transformador histórico, ela não se reduz à horizontalidade de suas ações. Em última instancia, a esperança opera num registro de excesso gratuito para além, embora jamais aquém, das causalidades humanas na história.

\section{Referências}

ALVES, Rubem. "Deus morreu - Viva Deus!". In: ALVES, Rubem; MOLTMANN, Jürgen; SANTA ANA, Júlio de; LEPARGNEUR, Hubert; GORGULHO, Gilberto. Liberdade e fé. Rio de Janeiro: Tempo e Presença, 1972.

Paulinas, 1982.

O suspiro dos oprimidos. São Paulo: Paulinas, 1984.

A gestação do futuro. Campinas: Papirus, 1987. 
. O enigma da religião. Campinas: Papirus, 2006.

. O que é religião? São Paulo: Loyola, 2014.

. Por uma teologia da libertação. Juiz de Fora/São Paulo: Siano/Recriar, 2019.

ARENDT, Hannah. A dignidade da política: ensaios e conferências. Rio de Janeiro: RelumeDumará, 1993.

CABRAL, Alexandre Marques. Niilismo e Hierofania: uma abordagem a partir do confronto entre Nietzsche, Heidegger e a tradição cristã. Rio de janeiro: MAUAD X/FAPERJ, 2 Vol., 2014.

CASANOVA, Marco Antônio. O instante extraordinário: Vida, História e Valor na obra de F. Nietzsche. Rio de Janeiro: Forense Universitária, 2003.

Nada a caminho: Impessoalidade, niilismo e técnica na obra de Martin Heidegger. Rio de Janeiro: Forense Universitária, 2006.

Compreender Heidegger. Petrópolis: Vozes, 2009.

HEIDEGGER, Martin. Sein und Zeit. Tübingen: Max Niemeyer, 2006.

FREIRE, Paulo. Pedagogia do oprimido. Rio de janeiro: Paz e Terra, 2013.

. Pedagogia da autonomia. Rio de Janeiro/São Paulo: Paz e Terra, 2018.

NIETZSCHE, Friedrich. Sämtliche Werke. Kritische Studienausgabe. Edição organizada por Giorgio Colli e Mazzino Montinari. 15 Vols. Berlim: Walter de Gruyter, 1967-1978.

Letras, 2002.

A gaia ciência. Trad. de Paulo César de Souza. São Paulo: Companhia das

Assim falou Zaratustra - um livro para todos e para ninguém. Trad. de

Mário da Silva. Rio de Janeiro: Civilização Brasileira, 2003.

Submetido em: 2-12-2021

Aceito em: 21-1-2022 